\title{
ANALISIS PENDAPATAN TENAGA KERJA USAHA AYAM POTONG TERHADAP KESEJAHTERAAN MASYARAKAT DI KABUPATEN BIREUEN
}

\author{
Juniar *a Khairil Anwar *b \\ *Fakultas Ekonomi dan Bisnis Universitas Malikussaleh \\ a Corresponding author: niajuniar46@gmail.com \\ b khairil.anwar.semsi1997@gmail.com
}

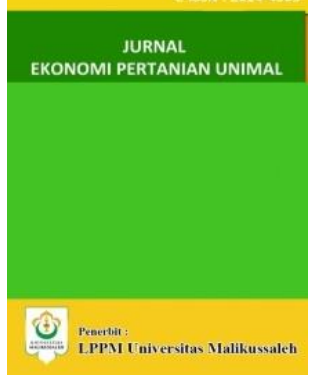

A R T I CLEINFORMATION

Keywords:

Keywords: income and welfare

\begin{abstract}
A B T R A C T
The purpose of this study is to look the effect of labor income of conducted in Bireuen District. The data used in this study are primary data sourced from 63 respondents. The data analysis method used in this study is a simple linear regression with the help of the eviews 10 program package. The results showed that the variable of labor income affects welfare and the magnitude of the effect of variable labor income on welfare by 0.0585 (5.85\%). Recommendations, it is hoped that the local government will socialize the importance of the broiler business carried out in Bireuen Regency for the welfare of the community.
\end{abstract}

\section{PENDAHULUAN}

Permintaan terhadap produk peternakan meningkat setiap tahun seiring dengan bertambahnya jumlah penduduk serta meningkatnya pengetahuan dan kesadaran masyarakat tentang pentingnya mengonsumsi pangan yang bergizi. Pada tahun 2018, kontribusi produk peternakan (daging, telur, dan susu) terhadap Produk Domestik Bruto (PDB) pertanian mencapai $12 \%$ dan terhadap PDB nasional sebesar $3 \%$. Sebagian besar $(97 \%)$ produksi telur berasal dari peternakan ayam ras (Statistik, 2019). Dengan adanya usaha ternak ayam potong memberikan kontribusi baik bagi masyarakat, dengan adanya usaha ini telah membuka lapangan pekerjaan bagi masyarakat yang dulunya menganggur, dengan adanya pekerjaan pada usaha tersebut telah membantu masyarakat dalam memenuhi

kebutuhan hidupnya sehingga kesejahteraan masyarakat dapat meningkat.

Ayam peliharaan dari daerah tropis merupakan sumber pangan paling penting di dunia $^{2}$. Namun, usaha peternakan ayam lokal belum berkembang antara lain karena belum tersedianya bibit unggul serta cara budi daya yang tidak efisien. Di negara berkembang, usaha ternak ayam lokal berperan penting dalam meningkatkan pendapatan masyarakat karena usaha tersebut melibatkan sebagian besar penduduk miskin ${ }^{3}$. Upaya pengembangan tersebut diharapkan pula dapat menggairahkan perekonomian dan sekaligus meningkatkan pendapatan masyarakat, terutama di perdesaan, karena Indonesia memiliki sumber daya alam yang memadai untuk menciptakan bibit 
unggul, bahan pakan, dan obat-obatan yang dibutuhkan dalam industri peternakan ayam modern, intensif, dan efisien. Kondisi peternakan ayam potong rakyat dan mandiri semakin memperihatinkan. Dalam tujuh bulan terakhir, kerugian sektor ini disinyalir mencapai $\mathrm{Rp} 1.4$ milliyar akibat harga jual ayam potong hidup yang terus anjlok di pasaran. Saat ini harga jual rata-rata menyentuh terendah dalam beberapa tahun terakhir yakni Rp 35.000- 45.000 per ekor. Faktor beragam, mulai dari tingginya biaya sarana produksi akibat naiknya harga bibit ayam dan harga pakan hingga kelebihan produksi ayam potong di pasaran, kelebihan produksi ini terjadi akibat banjirnya produk dari perusahaan peternakan terintegrasi, serta diikuti oleh lemahnya permintaan di tingkat konsumen (CNBC online, 2019).

Namun dengan terjadi isu seperti itu, di Kabupaten Bireuen masyarakat peminat ayam potong tetap aktif dalam membeli, masyarakat tidak melihat pada harga sisi naik turun, namun kebutuhan yang setiap harinya harus terpenuhi, sehingga harga bukan penyebab masyarakt tidak ingin mengkonsumi ayam potong.

Observasi awal diperoleh dari responden yang menjadi lokasi di penelitian ini sebagai berikut:
Tabel 1

Pendapatan, Pengeluaran dan Jumlah Anggota Keluarga

\begin{tabular}{|c|c|c|c|}
\hline $\begin{array}{c}\mathrm{N} \\
\mathrm{o}\end{array}$ & $\begin{array}{c}\text { Pendapatan } \\
(\mathrm{Rp})\end{array}$ & $\begin{array}{c}\text { Pengeluaran } \\
(\mathrm{Rp})\end{array}$ & $\begin{array}{c}\text { Jumlah Anggota } \\
\text { Keluarga } \\
\text { (Jiwa) }\end{array}$ \\
\hline 1 & 1.500 .000 & 1.800 .000 & 5 \\
\hline 2 & 1.800 .000 & 2.000 .000 & 7 \\
\hline 3 & 1.100 .000 & 1.000 .000 & 3 \\
\hline 4 & 1.200 .000 & 2.300 .000 & 4 \\
\hline 5 & 1.500 .000 & 1.800 .000 & 4 \\
\hline
\end{tabular}

Sumber: Observasi Awal

Berdasarkan observasi awal yang yang diperoleh dengan lima responden bahwa rata-rata kesejahteraan mereka masih kurang. Dapat kita lihat dari satu dari responden pertama rata-rata pendapatan perbulan Bapak Edo sebesar Rp 1.500.000 dengan tingkat pengeluaran $\mathrm{Rp}$ 1.800.000, total anggota dalam keluarga yang harus dipenuhi sebanyak 5 jiwa, dengan pengeluaran dan pendapatan beliau masih jauh dari kata sejahtera, dimana setiap bulannya harus ada hutang-hutang yang harus dilunasi dengan pencapaian pendapatan segitu beliau harus mampu mencukupi kehidupannya. Untuk responden selanjutnya masih sama kasus seperti Bapak Edo setiap harinya mereka harus memiliki inisiatif untuk dapat memperoleh penghasilan yang lebih demi mencukupi kebutuhan sehari-hari, berbagai cara mereka lakukan sama seperti Bapak Edo jalan satu-satunya ketika mereka sudah tidak mampu memenuhi kebutuhan hari ini mereka akan melakukan bon untuk memproleh kebutuhan mereka, sehingga sampai sejauh ini selama 
melakukan observasi awal para pekerja di Industri ayam potong Kabupaten Bireuen masih bisa dikatakan jauh dari kata sejahtera dilihat dari berbagai faktor, namun pada observasi awal ini yang dapat kita katakan masih sejahtera adalah bapak Hasyim, pendapatan beliau sebesar Rp 1.100.000 namun pengeluaran keluarga beliau Rp 1.000.000 dikarenakan jumlah anggota keluarga beliau sebanyak 3 jiwa dengan jumlah anak 1 jiwa dan belum terlalu banyak kebutuhan yang dikeluarkan perharinya.

Penelitian ini didukung oleh penelitian (Awang, 2014) dengan judul pengaruh pertumbuhan industri terhadap kesejahteraan masyarakat di provinsi Kalimantan Timur bahwa semua variabel yang diteliti memiliki pengaruh terhadap kesejahteraan masyarakat tersebut.

Peneliti selanjutnya dari Ricko (2016) dengan judul pengaruh kebijakan pemerintah di sektor batik terhadap kesejahteraan pelaku industri batik di Kota Pekalongan bahwa kebijakan pemerintah yang diambil di sektor bali berpengaruh terhadap kesejahteraan pelaku industri tersebut.

Tujuan yang akan disampaikan daalam penelitian yaitu untuk melihat seberapa besar pengaruh pendapatan tenaga kerja terhadap tingkat kesejahteraan masyarakat dengan adanya usaha Ayam Potong di Kabupaten Bireuen.

Selanjutnya pembahasan dibagian kedua dalam artikel ini adalah kajian teoritis, dibagian ketiga dibahas metode penelitian, pada bagian keempat membahas hasil dan pembahasan dan bagian kelima penutup dengan kesimpulan dan saran.

\section{KAJIAN TEORITIS}

\section{Kesejahteraan}

Kesejahteraaan merupakan penghidupan sosial yang didalam terdapat ras keselamatan dan ketentraman lahir dan bathin yang dirasakan masyarakat untuk memenuhi kebutuan hiduonya (Mukhlisisn, 2010).

Kesejahteraan masyarakat adalah suatu kondisi yang memperlihatkan tentang keadaan kehidupan masyarakat yang dapat dilihat dari standar kehidupan masyarakat ${ }^{5}$.

Berdasarkan pakar tersebut dapat diambil kesimpulan kesejahteraan adalah mampu terpenuhinya segala keperluan primer maupun sekunder untuk bertahan hidup.

Menurut penelitian yang dilakukan oleh ${ }^{6}$ kesejahteraan adalah tingkat terpenuhinya pemenuhan kualitas hidup keuarga pelaku usaha. 
Menurut penelitian yang dilakukan oleh ${ }^{7}$ kesejahteraan adalah kehidupan masyarakat yang sudah layak sehingga dapat memenuhi kebutuhan keluarga.

Kemudian menurut penelitian yang dilakukan oleh ${ }^{8}$ kesejahteraan merupakan tingkat kelayakan hidup masyarakat dalam memnuhi kebutuhan dengan mampu terpenuhinya segala keperluan baik primer maupun sekunder.

\section{Pendapatan}

Pendapatan adalah sejumlah dana yang diperoleh dalam rumah tangga dalam jangka waktu tertrntu ${ }^{9}$.

Pendapatan ialah dana yang diterima sesorang dalam bentuk gaji, upah maupun kompensasi ${ }^{10}$.

Berdasarkan pakar tersebut dapat diambil kesimpulan pendapatan adalah sejumlah dana yang diterima atas balas jasa yang dilakukan dengan kesepakatan tertentu.

Hubungan antara variabel pendapatan memiliki hubungan positif terhadap kesejahteraan masyarakat, dimana ketika semakin tinggi pendapatan seseorang maka akan meningkatkan konsumsi seseorang ${ }^{11}$ dilihat dari ketika seseorang memiliki pendapatan tinggi akan semakin banyak peluang untuk berbelanja sehingga akan meningkatkan konsumsi rumah tangga sehingga kesejahteraan masyarakat akan membaik, tidak hanya memenuhi kebutuhan dasar namun akan melakukan pembelian terhadap kebutuhan sekunder.

Menurut penelitian yang dilakukan oleh ${ }^{12}$ pendapatan adalah hasil yang diperoleh atas pekerjaan yang telah dilakukan.

Kemudian hasi teliti dari ${ }^{13}$ pendapatan merupakan total penerimaan dalam bentuk nominal dari seseorang atas apa yang telah dikerjakan guna memenuhi kebutuhan keluarga.

Dan menurut penelitian yang dilakukan oleh ${ }^{14}$ pendapatan adalah hasil peroleh dalam bentuk uang untuk memenuhi kebutuhan keluarga.

\section{Kerangka Konseptual}

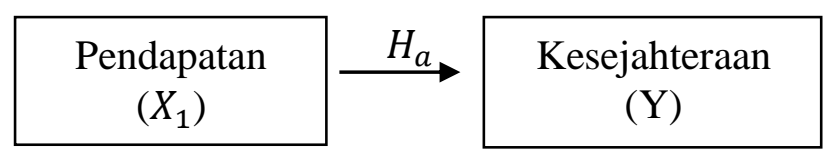

\section{Gambar 1 Kerangka Konseptual}

Kerangka konseptual diatas menjelaskan tentang hubungan variabel bebas terhadap variabel terikat yang akan diuji dengan secara parsial. Pada kerangka tersebut yang diuji adalah pendapatn secara parsial berpengaruh terhadap kesejahteraan. 


\section{Hipotesis}

Berdasarkan kerangka konseptual yang dikemukakan diatas, maka dapat dirumuskan hipotesis alternatif bahwa:

$H_{0}$ : Diduga pendapatan usaha ayam potong tidak berpengaruh secara positif terhadap kesejahteraan masyarakat di Kabupaten Bireuen.

$H_{a}$ : Diduga pendapatan usaha ayam potong berpengaruh secara positif terhadap kesejahteraan masyarakat di Kabupaten Bireuen.

\section{METODE PENELITIAN}

\section{Populasi}

Dari hasil survey yang peneliti lakukan, maka populasi penelitian ini yaitu pekerja di Industri ayam potong di Kabupaten Bireuen berdasarkan 4 kecamatan yaitu kecamatan Peusangan sebanyak 20 jiwa, kecamatan peusangan siblah krueng sebanyak 15 jiwa, kecamatan Peusangan Selatan sebanyak 18 jiwa dan Peusangan Kuta Blang sebanyak 10 jiwa sehingga populasi berjumlah 63 jiwa (Observasi lapangan, 2019).

\section{Sampel}

Dalam menentukan jumlah sampel dihitung berdasarkan metode sensus. sehingga sampel yang digunakan pada penelitian ini sebanyak 63 responden.

\section{Definisi Operasional Variabel}

a. Pendapatan $\left(X_{1}\right)$ : sejumlah dana yang diterima atas balas jasa yang dilakukan dengan kesepakatan tertentu. Diukur dengan satuan rupiah.

b. Kesejahteraan $(Y)$ : mampu terpenuhinya segala keperluan primer maupun sekunder untuk bertahan hidup. Diukur dengan satuan persen $(\%)$.

\section{Metode Analisis data}

Untuk memecahkan masalah pada penelitian ini maka penulis melakukan analisis data dengan memakai metode kuantitatif yaitu suatu metode menganalisis data yang diperoleh dalam bentuk angka dan selanjutnya akan dibahas serta di analisis dengan menggunakan alat statistik yaitu program Eviews versi 10 yang berupa metode (RLS) sebagai berikut:

$$
\log Y=\beta_{0}+\beta_{1} \log X_{1}
$$

Keterangan:

$\begin{array}{ll}\log \boldsymbol{Y} & =\text { Kesejahteraan } \\ \boldsymbol{\beta}_{\mathbf{0}} & =\text { Konstanta } \\ \boldsymbol{\beta}_{\mathbf{1}} & =\text { Koefisien Regresi } \\ \log \boldsymbol{X}_{\mathbf{1}} & =\text { Pendapatan }\end{array}$




\section{Uji Normalitas}

Uji normalitas dilakukan untuk melihat apakah angka yang diperolhe dalam penelitian normal atau tiak normal dapat dilakukan menggunakan metode Jarque-Bera (J-B) ${ }^{15}$.

Jika nilai probability dari statistik J-B lebih besar dari taraf kepercayaan $5 \%(0,05)$ berarti bahwa residul data berdistribusi normal. Sebaliknya jika nilai probability dari statistik J-B lebih kecil dari taraf kepercayaan 5\% $(0,05)$ berarti bahwa residul data tidak berdistribusi normal ${ }^{15}$.

\section{Uji Asumsi Klasik}

Uji asumsi klasik adalah pengujian asumsiasumsi statistik yang harus dipenuhi pada analisis regresi linear berganda. Adapun uji asumsi klasik yang digunakan dalam penelitian ini adalah sebagai berikut:

\subsection{Uji Heteroskedastisitas}

Uji heteroskedastisitas bertujuan menguji apakah dalam model regresi terjadi ketidaksamaan variance dari residual atau pengamatan ke pengamatan yang lain ${ }^{16}$.

Metode pengujian yang lain dapat digunakan adalah metode White dasar Pengambilan keputusan, jika nilai probabilitas dari Obs*R-Squared $>X^{2}$ tabel, maka ada indikasi terjadi heteroskedastisitas; jika nilai probabilitas dari $O b s^{*} R$-Squared $<X^{2}$ tabel, maka model tersebut terbebas dari heteroskedastisitas.

\section{Pengujian Hipotesis}

\subsection{Uji t}

Uji $\mathrm{t}$ dilakukan untuk melihat pengaruh vairabel bebas terhadap variabel terikat secara pasial ${ }^{17}$. Adapun kriteria pengujiannya adalah sebagai berikut:

1. Jika $t_{\text {hitung }}>t_{\text {tabel }}$ Ho ditolak dan menerima Ha yang artinya variabel bebas (X) secara parsial mempengaruhi variabel terikat (Y).

2. 2. Jika $t_{\text {hiutng }}<t_{\text {tabel }}$ maka Ho diterima dan menolak Ha yang artinya variabel bebas (X) secara parsial tidak mempengaruhi vaiabel terikat (Y).

\section{Koefisien Korelasi $(\mathbf{R})$}

Menurut ${ }^{18}$ Koefisien korelasi adalah sebuah angka yang dapat dijadikan petunjuk untuk mengetahui seberapa besar kekuatan korelasi di antara variabel yang sedang diselidiki korelasinya.

Pedoman untuk memberikan interpretasi koefisien sebagai berikut (Sugiyono, 2013):

- $>0,00-0,199=$ sangat rendah

- $>0,20-0,399=$ rendah

- $\quad>0,40-0,599=$ sedang

- $>0,60-0,799=$ kuat 
- $>0,80-0,99=$ sangat kuat

$->1=$ korelasi sempurna

\section{Koefisien Determinasi $\left(R^{2}\right)$}

Koefisien determinasi $\left(R^{2}\right)$ adalah satu ukuran yang digunakan untuk mengukur pengaruh variabel independen terhadap variansi dependen, dengan $0<R^{2}<1$.

\section{HASIL PENELITIAN DAN}

\section{PEMBAHASAN}

\section{Hasil Regresi Linier Sederhana}

Untuk melihat hasil estimasi model penelitian data yang diolah dengan bantuan program Eviews versi 10 maka diperoleh hasil perhitungan analisis regresi seperti yang ditunjukkan pada gambar berikut ini:

\section{Tabel 2}

Hasil Analisis Regresi Linear Sederhana Dependent Variable: LOG(KESEJAHTERAAN)

\begin{tabular}{|c|c|c|c|c|c|}
\hline Variable & Coefficient & Std. Error & t-Statistic & Prob. & ST \\
\hline C & 11.97731 & 1.135705 & 10.54614 & 0.0000 & normal. Hal ini juga bisa dilihat dari probabilitas \\
\hline LOG(PENDAPATAN) & 0.153537 & 0.078850 & 1.947217 & 0.0561 & \\
\hline R-squared & $0.058521 A$ & usted R-squ & & 0.043087 & \\
\hline
\end{tabular}

memberi arti jika variabel pendapatan meningkat sebesar $1 \%$ maka akan meningkatkan variabel Kesejahteraan sebesar $0.153537 \%$.

\section{Uji Normalitas}

Hasil Uji normalitas dapat dilihat pada gambar berikut ini:

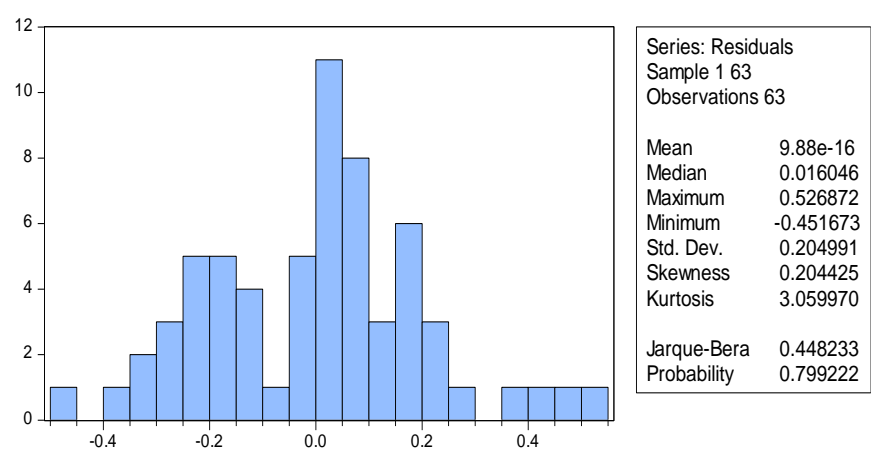

Sumber: Hasil Penelitian, 2019 (data diolah)

\section{Gambar 2 Uji Normalitas}

Nilai $X^{2}$ tabel dengan $\operatorname{df}(1)=3,84$. Jika dibandingkan dengan nilai J-B pada tabel diatas sebesar $0,45<3,84$, maka dapat disimpulkan bahwa model regresi, variabel penggangu atau Sumber: Hasil Penelitian, 2019 (data diolah)

Nilai konstanta sebesar 11.97731 artinya jika variabel pendapatan dianggap konstan, maka variabel kesejahteraan juga akan konstan sebesar 11.97731 .

\section{Hasil Uji Asumsi Klasik}

\subsection{Hasil Uji Heteroskedastisitas}

Hasil uji heteroskedastisitas dapat dilihat pada hasil berikut ini:

Nilai koefisien regresi pendapatan sebesar 0.153537 menunjukkan hubungan positif yang 
Tabel 3

Uji Heteroskedastisitas

Heteroskedasticity Test: White

\begin{tabular}{llll}
\hline \hline F-statistic & 0.135893 & Prob. F $(1,61)$ & 0.7137 \\
Obs ${ }^{*}$-squared & 0.140036 & Prob. Chi-Square(1) & 0.7082 \\
Scaled explained SS & 0.135223 & Prob. Chi-Square(1) & 0.7131 \\
\hline \hline
\end{tabular}

Sumber: Hasil Penelitian, 2019 (data diolah)

Berdasarkan Tabel di atas menunjukkan

bahwa data model yang digunakan dalam penelitian ini terbebas dari heteroskedastisitas, dari hasil tersebut dilihat dari obs*R-Squared < $X^{2}$ tabel pada $\operatorname{df}(1)=3,84$, sehingga $0,71<0,14$.

Hal ini juga bisa dilihat dari nilai probability (P-

value) sebesar $0,71>0,05$.

\section{Pengujian Hipotesis}

\subsection{Uji t}

Hasil pengujian dapat dilihat pada dibawah ini:

\section{Tabel 4}

Uji T

\begin{tabular}{|l|l|l|l|l|}
\hline \multicolumn{5}{|c|}{ Variabel Dependen (Kesejahteraan) } \\
\hline $\begin{array}{l}\text { Varibael } \\
\text { Independen }\end{array}$ & $\begin{array}{l}\text { T- } \\
\text { Statistik }\end{array}$ & Prob & Keterangan & Hipotesis \\
\hline Pendapatan & 1,95 & 0,0561 & Signifikan & Diterima \\
\hline
\end{tabular}

Sumber: Hasil Penelitian, 2019 (data diolah)

Dari Tabel dapat dilihat bahwa nilai $t_{h i t u n g}$ dari pendapatan adalah sebesar 1.95 dengan nilai signifikannya adalah 0,0561 , sementara nilai $t_{\text {tabel }}$ dengan $(\mathrm{df})=\mathrm{n}-\mathrm{k}(63-2=61)$ pada $\alpha=0,1$ diperoleh nilai sebesar 1,67 artinya kecil dari derajat kesalahan sebesar $10 \% \quad(0,1)$. Maka keputusannya menolak $H_{0}$ dan menerima $H_{1}$, yang berarti secara parsial pendapatan berpengaruh positif terhadap kesejahteraan masyakarakat di Kabupaten Bireuen.

\section{Koefisien Korelasi (R)}

Nilai koefisien korelasi adalah $R=\sqrt{R^{2}}=$ $\sqrt{0,0585}=0,2419(24,19 \%)$ yang menunjukkan bahwa hubungan antara variabel pendapatan terhadap konsumsi memiliki hubungan yang rendah secara positif karena nilai korelasi 0, 2419 jauh mendekati positif satu (+1).

\section{Koefisien Determinasi $\left(R^{2}\right)$}

Secara sederhana koefisien determinasi dihitung dengan mengkuadratkan koefisien korelasi (R).

\begin{tabular}{|l|l|}
\hline \multicolumn{4}{|c|}{ Adjusted R-Squared $=0,0585$} \\
\hline Maka nilai koefisien determinasi $\left(R^{2}\right)$
\end{tabular}
sebesar 0,0585 yang artinya bahwa ada kaitan antara variabel bebas dan variabel terikat, perubahan yang terjadi pada variabel terikat dapat dijelaskan oleh variabel bebas sebesar 0,0585 $(5,85 \%)$, sedangkan yang dipengaruhi oleh variabel lain diluar model ini adalah sebesar 1$0,0585=0,9415(94,15 \%)$.

\section{Pembahasan}

\section{a. Pengaruh Pendapatan Terhadap}

\section{Kesejahteraan}

Berdasarkan hasil analisis data ditemukan bahwa variabel pendapatan $\left(X_{1}\right)$ berpengaruh 
secara positif terhadap kesejahteraan (Y) dengan nilai signifikan $\alpha=10 \%$. Hal ini bermakna bahwa semakin tinggi pendapatan $\left(X_{1}\right)$, maka semakin tinggi pula kesejahteraan masyarakat di Kabupaten Bireuen.

Hasil penelitian ini sejalan dengan penelitian yang dilakukan oleh ${ }^{7}$ di provinsi Kalimantan Timur bahwa sektor industri pada berpengaruh secara signifikan terhadap kesejahteraan masyarakat, tetapi tidak cukup berarti membangkitkan pertumbuhan ekonomi, karena dominannya subsektor kehutanan, minyak dan gas.

Penelitian yang dilakukan oleh ${ }^{8}$ dengan judul Peran sektor peternak Ayam pedaging dalam perekonomian Kabupaten Kuantan Singingi Provinsi Riau hasil penelitian bahwa Karakteristik pengusaha ayam pedaging rata-rata umur pengusaha 37 tahun, lama pendidikan 12 tahun, pengalaman berusaha 4 tahun, dan jumlah tanggungan keluarga 3 jiwa. Usaha peternakan ayam pedaging masih dalam skala kecil. .

\section{PENUTUP}

\section{a. Kesimpulan}

Berdasarkan hasil olahan data yang diperoleh penulis melalui kuisioner dan hasil olahan data dengan regresi linier sederhana maka dapat diambil kesimpualn yaitu: Hasil yang ditemukan variabel pendapatan berpengaruh secara positif terhadap kesejahteraan. Adanya pengaruh ini menunjukkan bahwa seiring dengan terjadinya peningkatan pendapatan, maka kesejahteraan juga akan meningkat dan besarnya pengaruh pendapatan terhadap kesejahteraan adalah sebesar 5,85\%, dan sisanya sebesar 1$0,0585=0,9415(94,15 \%)$ dapat dijelaskan diluar model penelitian ini.

\section{b. Saran}

Adapun beberapa saran-saran yang diharapkan penulis dalam penelitian ini adalah sebagai berikut bahwa variabel yang diteliti berpengaruh terhadap kesejahteraan, tingginya pendapatan berpengaruh positif terhadap kesejahteraan, dengan tingginya pendapatan masyarakat mampu memenuhi kebutuhan hidup keluarganya dengan mampu memenuhinya maka akan terciptanya kesejahteraan. Diharapkan kepada pemerintah dapat membantu dalam mengatasi kesenjangan sehingga kesejahteraan masyarakat merata dan perlu adanya penelitian lanjutan, sehingga diperoleh temuan yang lebih bervariasi dan lebih baik dalam menjelaskan permintaan dengan metode penelitian yang berbeda. 


\section{DAFTAR PUSTAKA}

1. Statistik BP. PDRB Kabupaten Bireuen.; 2007.

2. Council NR. Mananging Global Livestock Resource. Commitee on Managing Global Genetic Resources. Washington DC.USA: Agricultural Imperatives. National Academic Press; 1993.

3. BSonaiya E. Family Poultry, Food Security and the Impact of HPAI. . World's Poult. Sci.; 2007.

4. Maeswara G. Biografi Prolitik Susilo Bambang Yudhoyono. Jakarta: Narasi; 2009.

5. Sukirno S. Makro Ekonomi Teori Pengantar Edisi Ketiga. Jakarta: PT. Rajawali Pers; 2015.

6. Ricko H. Pengaruh Kebijakan Pemerintah di Sektor Batik Terhadap Kesejahteraan Pelaku Industri Batik di Kota Pekalongan. Ruang. 2016;2(4).

7. Awang I. Pengaruh Pertumbuhan Industri Terhadap Kesejahteraan Masyarakat di Provinsi Kalimantan Timur. Ekon dan Bisnis. 2014; Xx(1).

8. Kurniati. Peran Sektor Peternak Ayam Pedaging Dalam Perekonomian Kabupaten Kuantan Singingi Provinsi Riau. Peternak Indones. 2014;16(3).

9. Samuelson PA dan WDN. Ilmu Mikro Ekonomi. Jakarta: PT Media Global Edukasi; 2001.

10. Jaya. Faktor-faktor yang Mempengaruhi Pendapatan Pedagang Kaki Lima di Sekitar Pantai Losari Kota Makkasar. 2011.

11. Todaro M. Pembangunan Ekonomi Edisi Kesembilan. Jakarta: PT. Erlangga; 2006.

12. Purwanti. Pengaruh Jumlah Tanggungan Keluarga, Pendapatan Terhadap Partisipasi Tenaga Kerja Wanita Pada Industri Kerupuk Kedelai di Tuntang Kabupaten Semarang. J Among Makarti. 2014;Vol 7 No.

13. Suarbawa, I Wayan, Terimajaya I Wayan DAPF. Pengaruh Umur, Jumlah Tanggungan Dan Jam Kerja Terhadap Pendapatan Tenaga Kerja Pengrajin Di Kecamatan Kediri. Ilm Untab. 2016;13(2).

14. Wahyono B. Analisis Faktor-faktor yang Mempengaruhi Pendapatan Pedagang di Pasar Bantul Kabupaten Bantul. Pendidik dan Ekon. 2017;6(4).

15. Widarjono A. Ekonometrika. Yogyakarta:

Edisi Keempat; 2013.
16. Ghozali I. Aplikasi Analisis Multivariate Dengan Program SPSS Edisi I. Bogor:

Universitas Dipenogoro; 2010.

17. Subri. Ekonomi Sumber Daya Manusia. (Persada PRG, ed.). Jakarta; 2013.

18. Sugiyono. Statistik Untuk Penelitian. Bandung: Alfabeta; 2015. 